\title{
The Influence of Successor Knowledge and Successor Willingness on Innovation Capability with Absorptive Capacity Mediation Variables and Moderating Variables Perception on Leader's Approval
}

\author{
Indahyati Dwi Astuti \\ PT Eka Ormed Indonesia \\ indahyatidwi@gmail.com \\ https://doi.org/10.37715/rmbe.v1i2.2422
}

\begin{abstract}
This study aims to examine the effect of successor knowledge and successor willingness on innovation capability of family companies with absorptive capacity as a mediating variable and perception on leader's approval as a moderating variable. This study uses quantitative methods using SmartPLS for data processing. The number of respondents in this study were 113 family company successors who were selected using purposive sampling method. The results show that successor knowledge has no significant effect on innovation capability of family companies, successor willingness and absorptive capacity has a significant positive effect on innovation capability of family companies, absorptive capacity fully mediates the effect of successor knowledge on innovation capability of family companies, and the variable perception on leader's approval moderates the significant effect of successor willingness to innovation capability of family companies.
\end{abstract}

Keywords - Successor, Family Firm, Successor Knowledge, Successor Willingness, Innovation Capability, Absorptive Capacity.

\section{Introduction}

Based on data published by the World Economic Forum in The Global Competitiveness Report 2019, Indonesia's competitiveness index has decreased globally WEF (2019). In 2016 Indonesia was ranked 41 in the world with a value of 4.52. Then in 2017 it increased in rank to 36th position with a value of 4.68. In 2018 Indonesia shot down to rank 45 with a score of 64.9 and continued to decline by 5 places to position 50 in 2019 with a value of 64.6. This data is supported by the results of a survey from $\mathrm{PwC}$ in 2018 which stated that the biggest challenge faced by family companies was the need to innovate to keep ahead, namely the company's need to innovate to be able to keep moving forward ( $\mathrm{PwC}, 2018)$. On the other hand, innovation has an important role for a company. Innovation is one of the strategies that family companies can do to be sustainable (Liaqat et al., 2021). Innovation is considered to be an important source of a company's competitive advantage (Kozioł-Nadolna, 2020).

PT. Eka Ormed Indonesia (ORMED) is a family company that manufactures orthopedic implants, orthopedic instruments and other surgical instruments that has been established since 1999 in Surabaya, East Java. In an effort to produce new products, the company sets quality targets where the company must be able to produce new products, namely at least two products within one year. The resulting product must meet the standards of safe, quality, and efficacy. But in reality, the company has received product complaints several times with different cases. The complaint was caused by the company's fault. The error occurred due to the negligence of the quality control department which is under the R\&D and QC department. On the other hand, in creating an innovation a company cannot rely solely on existing knowledge. Enriching a company's knowledge base through external knowledge sources can also drive the pace and quality of innovation (S. K. Cohen \& Caner, 2016; West \& Bogers, 2014). A business can innovate better when the knowledge that is in the current system is used in conjunction with knowledge from external sources that are well internalized (Shu et al., 2012). The company's ability to utilize external knowledge is called absorptive capacity (W. M. Cohen \& Levinthal, 1989). These abilities are related to the process of acquisition, assimilation, transformation, and exploitation of knowledge (Zahra \& George, 2002). Absorptive capacity is closely related to identifying market opportunities and using new knowledge to create 
innovation (Xie et al., 2018). The better the company's absorptive capacity, it is hoped that it can increase the company's ability to innovate.

\section{Literature Review}

\subsection{Previous Research}

Research related to successor and innovation topics was researched by (Wang et al., 2019). The purpose of this research is to examine the effect of successor knowledge and successor willingness on corporate sustainable innovation. The study was conducted on 128 companies in Taiwan. The results show that successor knowledge has a significant positive effect on corporate sustainable innovation, successor willingness has a significant positive effect on corporate sustainable innovation, and leader approval strengthens the significant positive effect of successor willingness on corporate sustainable innovation.

Subsequent research was conducted by (Letonja \& Duh, 2016). This study aims to analyze the effect of the knowledge sharing process on innovation in family businesses. The results of the study indicate that the tacit knowledge transferred by the founder to the successor is important but it is not correct to say that it can directly improve the innovation ability of the successor. In order to be able to produce an innovation, this knowledge must be combined with the knowledge obtained by successors from outside the company.

Limaj (Limaj \& Bernroider, 2019) conducted research related to the influence of absorptive capacity on innovation. Absorptive capacity in this study is divided into two groups, namely potential absorptive capacity and realized absorptive capacity. The results showed that PAC had a significant positive effect on RAC, PAC had a significant positive effect on exploratory innovation, and RAC had a significant positive effect on exploratory innovation and exploitative innovation.

The next research related to the topic of innovation was carried out by (Xie et al., 2018). This study aims to examine the effect of absorptive capacity on the company's innovation performance. The study was conducted on 379 technology companies in China. The results show that the four dimensions of absorptive capacity, namely knowledge acquisition, knowledge assimilation, knowledge transformation, and knowledge exploitation have a significant positive effect on innovation performance.

\subsection{Theoretical basis}

\subsubsection{Dynamic Capability Theory}

According to Teece (1997, as cited in Arranz et al., 2020), dynamic capability theory is a theory that discusses the company's ability to integrate, build, and configure its competencies by looking at internal and external conditions in the face of environmental changes. This theory consists of two processes, namely strategic and operational processes. The strategic process is more directed to the process of finding and developing new opportunities, while the operational process is configuring internal and external capabilities (Giniuniene \& Jurksiene, 2015).

\subsubsection{Innovation Capability}

Innovation capability is the company's ability to acquire market knowledge and technical knowledge both from within and outside the company and to combine this knowledge to obtain creative ideas and produce valuable products (Song et al., 2008). Innovation is divided into two domains, namely technological novelty and market novelty (Jansen et al., 2006). The technological domain focuses on the technology, product, and service approach while the market domain focuses on the segment or market approach. The indicators used to measure the innovation capability variable are as follows:

1. Exploratory innovation

2. Exploitative Innovation

\subsubsection{Family company}

The business is managed with the aim of forming and achieving a business vision that is held by a group consisting of several family members and has the potential for sustainability to the next generation (Tirdasari \& Dhewanto, 2012). Family involvement is the main characteristic that distinguishes family business and non-family business which is reflected in the aspects of ownership, governance, management, succession, and employment (Intihar \& Pollack, 2012). 


\subsubsection{Successor Knowledge}

Successors are candidates who are prepared to fill strategic positions within the company in the future with the aim of ensuring the sustainability of key positions in the business (Wang et al., 2019). This is because successors will later play a major role in determining business prospects through their ability to make strategic decisions (Schell et al., 2020). Successor characteristics are divided into two categories, namely successor knowledge and successor willingness.

The measurement indicators for successor knowledge variables are as follows:

1. Successor's professional qualities and abilities in managing the business

2. Crisis awareness and response capability, is the successor's ability to identify and respond to change

3. Talent development and utilization capability, is the successor's ability to develop individuals and utilize existing resources

4. Interpersonal relationship, is a successor relationship with the community or work environment

5. Successor has plans to expand the company's business

6. Successors like challenging types of work

\subsubsection{Successor Willingness}

The successor's willingness reflects the emotions and intentions of the next generation towards the succession process and in taking over the family company (Parker, 2016). The measurement indicators for successor willingness variables are as follows:

1. Successor's desire to control the business in all aspects

2. Successor's desire creates prosperity in business

3. Successor's willingness to take the time to manage the business

4. Successor's willingness to give up work outside of managing the family business

5. Successor response to the views of others

6. Successor's desire to get recognition from predecessor

7. Successor flexibility in running a family business

2.2.6. Perception on Leader Approval

The succession process involves several parties, namely predecessors, successors (next generations), family members, and non-family members (Ongkowijoyo et al., 2020). During the succession process, predecessors still play an important role because decision making is still dominated by predecessors (Yuan, 2019). The measurement indicators for the perception on leader approval variable are as follows:

1. Predict the condition of the family business after the transition, whether the condition is getting better or getting worse.

2. The willingness of predecessors to delegate authority to their successors.

3. The spirit of predecessors in managing the business

4. predecessor pensiun retirement plan

5. The predecessor's trust in his successor

2.2.7. Perception on Leader Approval

Absorptive capacity is related to the company's ability to acquire, manage, and utilize external knowledge as an important process to identify market opportunities and use this knowledge to innovate (Xie et al., 2018). The measurement indicators for the absorptive capacity variable are as follows:

1. Knowledge acquisition

2. Knowledge assimilation

3. Knowledge transformation

4. Knowledge exploitation 


\section{Research Methods}

3.1. Analysis Model

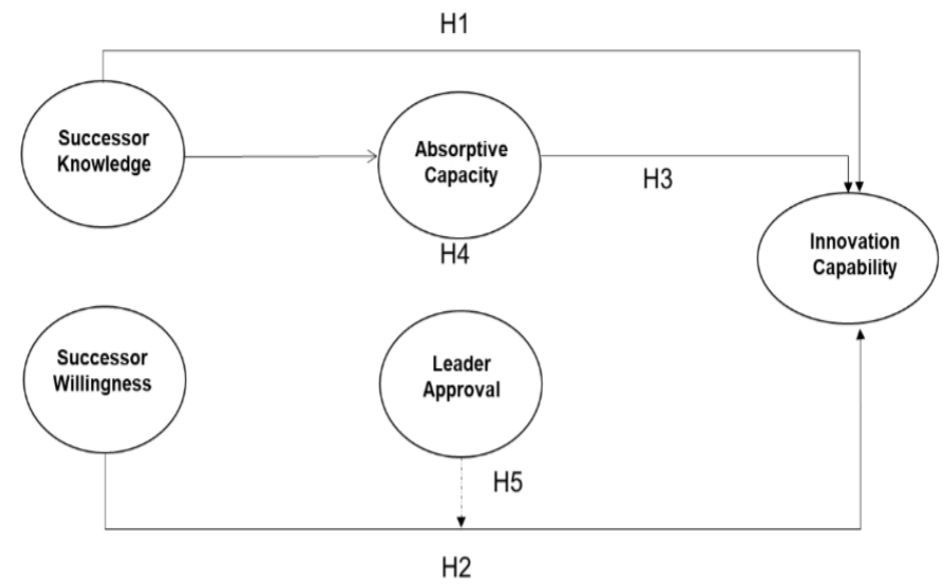

Figure 3.1. Hypothesis Framework

Based on the theoretical basis and previous research as written on the influence between variables, the research hypothesis is as follows:

H1: Successor knowledge has a significant effect on the innovation capability of family companies.

$\mathrm{H} 2$ : Successor willingness has a significant effect on the innovation capability of family companies.

H3: Absorptive capacity has a significant effect on the innovation capability of family companies.

H4: Absorptive capacity mediates the effect of successor knowledge on the innovation capability of family companies

H5: Perception of successor on leader's approval moderates the effect of successor willingness on innovation capability of family companies.

\section{2. $\quad$ Research Approach}

This study uses a quantitative approach. The research variables used in this study consisted of independent variables, namely successor knowledge, successor willingness, and absorptive capacity with the dependent variable being innovation capability. This study also uses a mediating variable, namely absorptive capacity and a moderating variable, namely perception on leader's approval. The minimum sample size in this method is greater than 10 times the largest number of structural paths directed at one construct in the structural model (Kock, 2018). The largest number of structural paths in this study that were directed to constructs in the structural model was 4 , thus the minimum sample size was 40 . The primary data in this study were obtained by distributing questionnaires to the respondents. Respondents who are the subjects of this study are successors who have been actively involved in the business for at least 1 year and have positions both formally and informally in the company. Company data can be obtained from the list of companies registered in Entrepreneurship groups such as Family Business Alumni, Ciputra University Students, Fambus MM UC students, and others.

\section{Result and Discussion}

\subsection{Overall Data Validity and Reliability}

\subsubsection{Overall Data Validity Test}

The first stage of the validation test is to perform convergent validity. Convergent validity is done by looking at the loading factor (outer loading) and AVE values. The outer loading value is said to be valid or ideal if it has a value of more than 0.7. From the results of the calculation of the pls algorithm, there are several indicators that show the outer loading value is less than 0.7. These indicators include AC3 (0.646), IC4 (0.647), IC13 (0.681), LA1 (0.591). Therefore, the deletion of these indicators was carried out. The next step is to see the AVE value. The AVE value generated for each variable is more than 0.5 so that it meets the requirements. The second stage in the data validity test is discriminant validity, namely by looking at the Fornell-Larcker value and cross 
loading. However, from the analysis of the Fornell-Larcker value, there is a correlation value that does not meet the requirements, namely the correlation value of the IC variable with IC (the variable itself) is smaller than the correlation value of the IC variable with SW. This finding requires the researcher to return to the outer loading table to delete the smallest value contained in the indicator.

After recalculation, the outer loading, AVE, and Fornell-Larcker values were re-checked to ensure that all of them met the requirements. The results show that these values have met the requirements. The next step is to check the cross loading value. The value of cross loading is accepted if the correlation value between indicators measuring the actual variables is greater than the correlation value between these indicators in measuring other variables.

Table 4.1. Final Outer Loading Results

\begin{tabular}{|l|r|l|r|l|r|l|r|}
\hline Indikator & Outer Loading & Indikator & Outer Loading & Indikator & Outer Loading & Indikator & Outer Loading \\
\hline AC1 & 0.753 & IC1 & 0.840 & LA2 & 0.831 & SW2 & 0.834 \\
\hline AC2 & 0.769 & IC2 & 0.821 & LA3 & 0.764 & SW3 & 0.857 \\
\hline AC4 & 0.737 & IC3 & 0.856 & LA4 & 0.807 & SW5 & 0.844 \\
\hline AC5 & 0.784 & IC5 & 0.843 & LA5 & 0.845 & SW6 & 0.883 \\
\hline AC6 & 0.723 & IC6 & 0.853 & SK1 & 0.872 & SW7 & 0.825 \\
\hline AC7 & 0.707 & IC7 & 0.810 & SK2 & 0.743 & SW*LA & 1.233 \\
\hline AC8 & 0.844 & IC9 & 0.824 & SK3 & 0.828 & & \\
\hline AC9 & 0.830 & IC10 & 0.839 & SK4 & 0.772 & & \\
\hline AC10 & 0.849 & IC11 & 0.841 & SK5 & 0.766 & & \\
\hline AC11 & 0.820 & IC12 & 0.843 & SK6 & 0.772 & & \\
\hline AC12 & 0.759 & IC15 & 0.855 & & & & \\
\hline AC13 & 0.776 & IC16 & 0.795 & & & & \\
\hline
\end{tabular}

Source: Data processed from SmartPLS 2021

Table 4.2. .Final AVE Results

\begin{tabular}{|l|c|}
\hline \multicolumn{1}{|c|}{ Variabel } & Nilai AVE \\
\hline Successor Knowledge & 0.629 \\
\hline Successor Willingness & 0.720 \\
\hline Absorptive Capacity & 0.609 \\
\hline Leader's Approval & 0.660 \\
\hline Innovation Capability & 0.698 \\
\hline Successor Willingness*Leader's Approval & 1.000 \\
\hline
\end{tabular}

Source: Data processed from SmartPLS 2021

Table 4.3. Final Fornell-Larcker Results

\begin{tabular}{|c|c|c|c|c|c|c|}
\hline Variabel & $\begin{array}{l}\text { Absorptive } \\
\text { Capacity }\end{array}$ & $\begin{array}{l}\text { Innovation } \\
\text { Capability }\end{array}$ & $\begin{array}{l}\text { Leader's } \\
\text { Approval }\end{array}$ & $\begin{array}{l}\text { Successor } \\
\text { Knowledge }\end{array}$ & $\begin{array}{c}\text { Successor } \\
\text { Willingness }\end{array}$ & $\begin{array}{c}\text { Successor } \\
\text { Willingness*Leader's } \\
\text { Approval }\end{array}$ \\
\hline Absorptive Capacity & 0.781 & & & & & \\
\hline Innovation Capability & 0.755 & 0.835 & & & & \\
\hline Leader’s Approval & 0.410 & 0.564 & 0.812 & & & \\
\hline Successor Knowledge & 0.510 & 0.471 & 0.247 & 0.793 & & \\
\hline Successor Willingness & 0.633 & 0.824 & 0.411 & 0.449 & 0.849 & \\
\hline $\begin{array}{l}\text { Successor } \\
\text { Willingness*Leader's } \\
\text { Approval }\end{array}$ & -0.313 & -0.532 & -0.057 & -0.169 & -0.585 & 1.000 \\
\hline
\end{tabular}

\section{Source: Data processed from SmartPLS 2021}

Table 4.4. Cross Loading Final

\begin{tabular}{|l|r|r|r|r|r|r|}
\hline & $\begin{array}{c}\text { Absorptive } \\
\text { Capacity }\end{array}$ & $\begin{array}{c}\text { Innovation } \\
\text { Capability }\end{array}$ & $\begin{array}{c}\text { Leaders } \\
\text { Approval }\end{array}$ & $\begin{array}{c}\text { Successor } \\
\text { Knowledge }\end{array}$ & $\begin{array}{c}\text { Successor } \\
\text { WIllingness_ }\end{array}$ & $\begin{array}{c}\text { Successor } \\
\text { Willingness*Leaders } \\
\text { Approval }\end{array}$ \\
\hline $\mathrm{AC} 1$ & 0.753 & 0.609 & 0.384 & 0.428 & 0.522 & -0.115 \\
\hline $\mathrm{AC} 10$ & 0.849 & 0.686 & 0.331 & 0.409 & 0.582 & -0.334 \\
\hline
\end{tabular}




\begin{tabular}{|c|c|c|c|c|c|c|}
\hline $\mathrm{AC} 11$ & 0.820 & 0.731 & 0.438 & 0.356 & 0.610 & -0.300 \\
\hline $\mathrm{AC} 12$ & 0.759 & 0.579 & 0.399 & 0.341 & 0.422 & -0.164 \\
\hline $\mathrm{AC} 13$ & 0.776 & 0.608 & 0.390 & 0.324 & 0.502 & -0.182 \\
\hline $\mathrm{AC} 2$ & 0.769 & 0.484 & 0.241 & 0.510 & 0.383 & -0.155 \\
\hline AC4 & 0.737 & 0.513 & 0.225 & 0.457 & 0.473 & -0.290 \\
\hline AC5 & 0.784 & 0.602 & 0.356 & 0.456 & 0.513 & -0.331 \\
\hline AC6 & 0.723 & 0.516 & 0.349 & 0.403 & 0.408 & -0.113 \\
\hline AC7 & 0.707 & 0.526 & 0.235 & 0.302 & 0.546 & -0.340 \\
\hline AC8 & 0.844 & 0.571 & 0.242 & 0.395 & 0.432 & -0.200 \\
\hline AC9 & 0.830 & 0.605 & 0.222 & 0.386 & 0.509 & -0.389 \\
\hline IC1 & 0.730 & 0.840 & 0.488 & 0.365 & 0.652 & -0.361 \\
\hline IC10 & 0.657 & 0.839 & 0.431 & 0.274 & 0.687 & -0.422 \\
\hline IC11 & 0.523 & 0.841 & 0.417 & 0.436 & 0.738 & -0.489 \\
\hline IC12 & 0.532 & 0.843 & 0.472 & 0.412 & 0.697 & -0.529 \\
\hline IC15 & 0.760 & 0.855 & 0.454 & 0.452 & 0.709 & -0.463 \\
\hline IC16 & 0.539 & 0.795 & 0.441 & 0.476 & 0.681 & -0.542 \\
\hline $\mathrm{IC} 2$ & 0.616 & 0.821 & 0.520 & 0.347 & 0.699 & -0.412 \\
\hline IC3 & 0.728 & 0.856 & 0.556 & 0.453 & 0.687 & -0.411 \\
\hline IC5 & 0.681 & 0.843 & 0.443 & 0.329 & 0.630 & -0.400 \\
\hline IC6 & 0.593 & 0.853 & 0.514 & 0.369 & 0.658 & -0.398 \\
\hline IC7 & 0.644 & 0.810 & 0.441 & 0.408 & 0.715 & -0.437 \\
\hline IC9 & 0.532 & 0.824 & 0.465 & 0.401 & 0.710 & -0.487 \\
\hline LA2 & 0.552 & 0.606 & 0.831 & 0.288 & 0.390 & -0.100 \\
\hline LA3 & 0.191 & 0.346 & 0.764 & 0.097 & 0.312 & 0.059 \\
\hline LA4 & 0.243 & 0.334 & 0.807 & 0.142 & 0.262 & 0.014 \\
\hline LA5 & 0.219 & 0.446 & 0.845 & 0.209 & 0.333 & -0.101 \\
\hline SK1 & 0.402 & 0.399 & 0.213 & 0.872 & 0.403 & -0.128 \\
\hline SK2 & 0.442 & 0.347 & 0.194 & 0.743 & 0.368 & -0.154 \\
\hline SK3 & 0.415 & 0.378 & 0.163 & 0.828 & 0.393 & -0.147 \\
\hline SK4 & 0.474 & 0.369 & 0.205 & 0.772 & 0.333 & -0.058 \\
\hline SK5 & 0.328 & 0.398 & 0.234 & 0.766 & 0.324 & -0.135 \\
\hline SK6 & 0.345 & 0.350 & 0.164 & 0.772 & 0.308 & -0.195 \\
\hline SW2 & 0.497 & 0.639 & 0.332 & 0.290 & 0.834 & -0.605 \\
\hline SW3 & 0.606 & 0.713 & 0.281 & 0.466 & 0.857 & -0.500 \\
\hline SW5 & 0.523 & 0.665 & 0.340 & 0.393 & 0.844 & -0.445 \\
\hline SW6 & 0.605 & 0.773 & 0.481 & 0.334 & 0.883 & -0.460 \\
\hline SW7 & 0.444 & 0.697 & 0.295 & 0.420 & 0.825 & -0.485 \\
\hline $\begin{array}{l}\text { Successor } \\
\text { WIllingness_ } \\
\text { *Leaders } \\
\text { Approval }\end{array}$ & -0.313 & -0.532 & -0.057 & -0.169 & -0.585 & 1.000 \\
\hline
\end{tabular}

\section{Source: Data processed from SmartPLS 2021}

\subsubsection{Overall Data Reliability Test}

In the reliability test, a check is made on the value of Cronbach's alpha and composite reliability which must have a value above 0.7 so that it is said to be good and feasible. Table 5.23 shows that the value of Cronbach's alpha and composite reliability is above 0.7 , which means that it has met the requirements.

Table 4.5. Cronbach's Alpha and Composite Reliability table

\begin{tabular}{|l|r|r|}
\hline & Cronbach's Alpha & Composite Reliability \\
\hline Absorptive Capacity & 0.941 & 0.949 \\
\hline Innovation Capability & 0.961 & 0.965 \\
\hline Leader's Approval & 0.835 & 0.886 \\
\hline Successor Knowledge & 0.881 & 0.910 \\
\hline Successor Willingness & 0.903 & 0.928 \\
\hline Successor Willingness*Leader's Approval & 1.000 & 1.000 \\
\hline
\end{tabular}




\subsection{Structural Model Test (Inner Model)}

\subsubsection{Goodness of Fit Test}

The first stage in the goodness of fit test is to look at the r-square value. The R-square of the results of the data processing is shown in Table 4.6. shows the number 0.260 on the variable absorption capacity and 0.825 on the variable innovation capability. This means that $26 \%$ of the dependent variable absorption capacity can be explained by the independent variable, namely successor knowledge and the remaining $74 \%$ is explained by other independent variables outside the study. Furthermore, the R-square value for innovation capability of 0.825 indicates that $82.5 \%$ of the innovation capability variable can be explained by the independent variables studied by the researchers, namely successor knowledge, successor willingness, absorptive capacity, and leader's approval, while the remaining $17.5 \%$ is explained by other variables that not used in the study. The NFI value in this study shows the number 0.631 , which is getting closer to 1 which indicates that the better the model is built.

Tabel 4.6. Value of R-Square

\begin{tabular}{|l|l|l|}
\hline & R-Square & Adjusted R-Square \\
\hline Absorption Capacity & 0.260 & 0.253 \\
\hline Innovation Capability & 0.825 & 0.817 \\
\hline
\end{tabular}

Source: Data processed from SmartPLS 2021

The next step is to look at the values in the path coefficients which show how the relationship between variables is. The results show that successor knowledge has a positive effect on absorptive capacity, then successor knowledge, successor willingness, absorptive capacity, and leader's approval have a positive effect on innovation capability, as well as leader's approval. Moderating the positive influence of successor willingness on innovation capability.

Table 4.7. Path-Coefficients Results

\begin{tabular}{|l|r|r|}
\hline & $\begin{array}{l}\text { Absorptive } \\
\text { Capacity }\end{array}$ & $\begin{array}{l}\text { Innovation } \\
\text { Capability }\end{array}$ \\
\hline Absorptive Capacity & & 0.331 \\
\hline Innovation Capability & & \\
\hline Leader's Approval & & 0.248 \\
\hline Successor Knowledge & 0.510 & 0.035 \\
\hline Successor Willingness & & 0.392 \\
\hline Successor Willingness*Leader's Approval & & -0.145 \\
\hline
\end{tabular}

\subsection{Hypothesis testing}

\section{Source: Data processed from SmartPLS 2021}

\subsubsection{Significance Test (Bootstrapping)}

An independent variable is said to have a significant effect if it has a t-statistic value of more than 1.96 or by looking at the p-value which is only said to be significant if the value is less than 0.05 .

Table 4.8. T-Statistics results

\begin{tabular}{|c|c|c|c|c|c|c|}
\hline & $\begin{array}{c}\text { Original } \\
\text { Sample }(O)\end{array}$ & $\begin{array}{c}\text { Sample } \\
\text { Mean (M) }\end{array}$ & $\begin{array}{l}\text { Standard } \\
\text { Deviation } \\
(\mathrm{STDEV})\end{array}$ & $\begin{array}{l}\text { T Statistics } \\
(|\mathrm{O} / \mathrm{STDEV}|)\end{array}$ & $\begin{array}{c}\mathrm{P} \\
\text { Values }\end{array}$ & Significance \\
\hline $\begin{array}{l}\text { Absorptive Capacity -> Innovation } \\
\text { Capability }\end{array}$ & 0.331 & 0.316 & 0.094 & 3.531 & 0.000 & Significant \\
\hline $\begin{array}{l}\text { Leader's Approval -> Innovation } \\
\text { Capability }\end{array}$ & 0.248 & 0.243 & 0.058 & 4.302 & 0.000 & Significant \\
\hline $\begin{array}{l}\text { Successor Knowledge -> Absorptive } \\
\text { Capacity }\end{array}$ & 0.510 & 0.528 & 0.102 & 4.998 & 0.000 & Significant \\
\hline $\begin{array}{l}\text { Successor Knowledge -> Innovation } \\
\text { Capability }\end{array}$ & 0.035 & 0.036 & 0.059 & 0.590 & 0.556 & $\begin{array}{l}\text { No } \\
\text { Significance }\end{array}$ \\
\hline $\begin{array}{l}\text { Successor Willingness -> Innovation } \\
\text { Capability }\end{array}$ & 0.392 & 0.405 & 0.081 & 4.833 & 0.000 & Significant \\
\hline $\begin{array}{l}\text { Successor Willingness*Leader's } \\
\text { Approval -> Innovation Capability }\end{array}$ & -0.145 & -0.141 & 0.047 & 3.062 & 0.002 & Significant \\
\hline
\end{tabular}


In table 4.8. it can be concluded that successor knowledge has no significant effect on innovation capability as indicated by the t-statistics value below 1.96, namely 0.590 . This means that $\mathrm{H} 1$ is rejected. Furthermore, the successor willingness variable has a significant effect on innovation capability as indicated by the t-statistics value of 4.833 where the value is more than 1.96. These results indicate that $\mathrm{H} 2$ is accepted. The variable absorptive capacity has a significant positive effect on innovation capability as indicated by the t-statistics value above 1.96 , namely 3.531, which means that $\mathrm{H} 3$ in this study is accepted. The successor knowledge variable has a significant effect on absorptive capacity as indicated by the t-statistics value of 4.998 where the value is $>1.96$. This means that the variable absorptive capacity fully mediates the relationship between successor knowledge and innovation capability ( $\mathrm{H} 4$ is accepted). The effect of the variable perception on leader's approval is significant in moderating the relationship between successor willingness to innovation capability as indicated by the t-statistics value of 3.062 (more than 1.96). Thus, H5 in this study is accepted.

\section{Conclusions and Practical Implication}

\subsection{Conclusion}

Based on the results of data processing, analysis, and discussion that have been carried out by researchers, it can be concluded that successor knowledge does not significantly affect the innovation capability of family companies. This shows that successor knowledge does not have a significant impact even though the relationship is positive. Successor willingness has a significant positive effect on the innovation capability of family companies. This shows that the higher the successor willingness, the higher the innovation capability of family companies. Absorptive capacity has a significant positive effect on the innovation capability of family companies. This shows that the higher the absorptive capacity, the higher the innovation capability of family companies. Absorptive capacity mediates the effect of successor knowledge on the innovation capability of family companies. On the other hand, successor knowledge has no effect on the innovation capability of the family company. Therefore, absorptive capacity has a role that is to fully mediate. Perception on Leader's Approval weakens the significant influence of successor willingness on innovation capability of family companies. This shows that when the leader is willing to delegate full authority to the successor in running a family business, it will have a negative impact or weaken the successor's willingness to innovate in the family company.

\subsection{Practical Implication}

Knowledge basically remains the driver of innovation, it's just that the management of family companies or previous generations (predecessors) need to pay attention to the importance of knowledge sharing as a way to utilize the knowledge of each individual so that it can become something of value for the company. Through the exchange of knowledge, individuals (successors) and other employees are able to respond to new information and the external environment more quickly, efficiently, in a solution, and ultimately increase the company's innovative capability.

In addition, the successor's willingness to run a family company can have an impact on the family company's ability to innovate. Although this factor does not consider the technical aspect (ability), a high willingness of successors can encourage them to be more enthusiastic in making the company more prosperous. A high desire to make the company bigger triggers successors to think more creatively. Therefore, predecessors need to maintain the motivation of their successors in running a family business in order to have a good impact on the company, especially innovation.

However, it should be noted that the full delegation of authority from the predecessor to the successor on the other hand can weaken the successor's influence in creating innovation. Such conditions do not always occur. However, in this study, the potential that causes this to happen is in terms of successor readiness and successor characteristics such as young age. Therefore, predecessors are expected to be able to see the level of readiness of the successors in managing the family business before giving them greater approval.

Absorptive capacity has a significant positive effect on the innovation capability of family companies. These results need to be an important concern for family companies so that they can be one of the strategies to be able to produce innovation, especially for manufacturing companies which are the majority of industrial types of companies in this study. PT. EOI as a manufacturing company needs to evaluate in more detail how the company's absorptive capabilities are. Companies are expected to pay more attention to how to improve their team's ability to acquire, 
manage, and utilize external and internal knowledge. That way the company will be better at identifying opportunities to innovate. Especially as a manufacturing company, both in terms of product and service innovation.

Regarding the absorptive ability of the family companies involved in this research, the company is still lacking in terms of knowledge transformation or related to the company's ability to combine existing knowledge with new knowledge gained. The company's low ability in this process can result in the difficulty of the company in identifying new opportunities. Therefore, companies need to improve the ability of employees to manage the information available in the company.

In terms of the ability to innovate family companies involved in this research, the company still has a fairly low score in terms of the ability to think outside the box. Therefore, companies need to improve the ability of their members to be able to think more creatively.

\section{References}

Arranz, N., Arroyabe, M., Li, J., \& Fernandez de Arroyabe, J. C. (2020). Innovation as a driver of eco-innovation in the firm: An approach from the dynamic capabilities theory. Business Strategy and the Environment, 29(3), 1494-1503. https://doi.org/10.1002/bse.2448

Cohen, S. K., \& Caner, T. (2016). Converting inventions into breakthrough innovations: The role of exploitation and alliance network knowledge heterogeneity. Journal of Engineering and Technology Management, 40, 29 44. https://doi.org/10.1016/j.jengtecman.2016.03.002

Cohen, W. M., \& Levinthal, D. A. (1989). Innovation and learning: The fwo faces of R\&D. The Economic Journal, 99(397), 569-596. https://doi.org/10.2307/2233763

Giniuniene, J., \& Jurksiene, L. (2015). Dynamic capabilities, innovation and organizational learning: Interrelations and impact on firm performance. Procedia - Social and Behavioral Sciences, 213, 985-991. https://doi.org/10.1016/j.sbspro.2015.11.515

Intihar, A., \& Pollack, J. M. (2012). Exploring small family-owned firms' competitive ability. Journal of Family Business Management, 2(1), 76-86. https://doi.org/10.1108/20436231211216439

Jansen, J. J. P., Van Den Bosch, F. A. J., \& Volberda, H. W. (2006). Exploratory innovation, exploitative innovation, and performance: Effects of organizational antecedents and environmental moderators. Management Science, 52(11), 1661-1674.

Kozioł-Nadolna, K. (2020). The role of a leader in stimulating innovation in an organization. Administrative Sciences, 10(3), 59. https://doi.org/10.3390/admsci10030059

Letonja, M., \& Duh, M. (2016). Knowledge transfer in family businesses and its effects on the innovativeness of the next family generation. Knowledge Management Research \& Practice, 14(2), 213-224. https://doi.org/10.1057/kmrp.2015.25

Liaqat, M. U., Haron, A. J., \& Bhatti, H. S. (2021). The effect of succession on family business innovation and leadership: Case analysis of Australia SMEs. Journal of Entrepreneurship \& Organization Management, $10(2), 1-8$.

Limaj, E., \& Bernroider, E. W. N. (2019). The roles of absorptive capacity and cultural balance for exploratory and exploitative innovation in SMEs. Journal of Business Research, 94, 137-153. https://doi.org/10.1016/j.jbusres.2017.10.052

Ongkowijoyo, G., Sutrisno, T. F. C. ., \& Teofilus, T. (2020). Performance achievements of family business through successor readiness and the relationship between family and business members. Jurnal Manajemen Teori Dan Terapan | Journal of Theory and Applied Management, 13(2), 198-214. https://doi.org/10.20473/jmtt.v13i2.19397

Parker, S. C. (2016). Family firms and the "willing successor" problem. Entrepreneurship Theory and Practice, 40(6), 1241-1259. https://doi.org/10.1111/etap.12242

PwC. (2018). Family business survey 2018. https://www.pwc.com/gx/en/services/family-business/family-businesssurvey-2018.html

Schell, S., de Groote, J. K., Moog, P., \& Hack, A. (2020). Successor selection in family business - A signaling game. Journal of Family Business Strategy, 11(3), 100286. https://doi.org/10.1016/j.jfbs.2019.04.005 
Shu, C., Page, A. L., Gao, S., \& Jiang, X. (2012). Managerial ties and firm innovation: Is knowledge creation a missing link? Journal of Product Innovation Management, 29(1), 125-143. https://doi.org/10.1111/j.15405885.2011.00883.x

Song, Z., Fan, L., \& Chen, S. (2008). Knowledge sharing and innovation capability: Does absorptive capacity function as a mediator? 2008 International Conference on Management Science and Engineering 15th Annual Conference Proceedings, 971-976.

Tirdasari, N. L., \& Dhewanto, W. (2012). Family business succession in Indonesia: A study of hospitality industry. Procedia - Social and Behavioral Sciences, 57, 69-74. https://doi.org/10.1016/j.sbspro.2012.09.1159

Wang, Y.-Z., Lo, F.-Y., \& Weng, S.-M. (2019). Family businesses successors knowledge and willingness on sustainable innovation: The moderating role of leader's approval. Journal of Innovation \& Knowledge, 4(3), 188-195. https://doi.org/10.1016/j.jik.2019.05.001

West, J., \& Bogers, M. (2014). Leveraging external sources of innovation: A review of research on open innovation. Journal of Product Innovation Management, 31(4), 814-831. https://doi.org/10.1111/jpim.12125

World Economic Forum (WEF). (2019). Statistical yearbook of Indonesia 2020.

Xie, X., Zou, H., \& Qi, G. (2018). Knowledge absorptive capacity and innovation performance in high-tech companies: A multi-mediating analysis. Journal of Business Research, 88, 289-297. https://doi.org/10.1016/j.jbusres.2018.01.019

Yuan, X. (2019). A review of succession and innovation in family business. American Journal of Industrial and Business Management, 09(04), 974-990. https://doi.org/10.4236/ajibm.2019.94066

Zahra, S. A., \& George, G. (2002). Absorptive capacity: A review, reconceptualization, and extension. The Academy of Management Review, 27(2), 185-203. https://doi.org/10.2307/4134351 